\title{
„Að preifa sig áfram í myrkrinu“: Ríkjandi stefnur og straumar um ungt flóttafólk í íslensku grunn- og framhaldsskólakerfi
}

\author{
Eva Harđardóttir, doktorsnemi, Menntavísindasvið, Háskóli Íslands \\ Berglind Rós Magnúsdóttir, dósent, Menntavísindasvið, Háskóli Íslands
}

\begin{abstract}
Útdráttur
prátt fyrir að Ísland taki ekki á móti flóttafólki í jafn ríkum mæli og aðrar Evrópupjóðir fer ungu flóttafólki hérlendis engu að síður fjölgandi í kjölfar alpjóðlegra og pvingaðra fólksflutninga. Á sama tíma má greina átakameiri umræðu um gildi fjölmenningar í aðlögun innflytjenda. Rannsóknir er varða nemendur af erlendum uppruna og skóla án aðgreiningar hérlendis hafa pó ekki beinst sérstaklega að stöðu ungs flóttafólks. Markmið pessarar rannsóknar er að kanna hvers konar menntastefna er við lýði um ungt flóttafólk á Íslandi með tilliti til menntunar og félagslegrar aðlögunar. Í anda gagnrýnna menntastefnufræða voru greind tvö opinber stefnuskjöl er snúa að móttöku og pjónustu við flóttafólk og fimm rýnihópaviðtöl við fjórtán grunn- og framhaldsskólakennara. Niðurstöður benda til að stefna um ungt flóttafólk sé takmörkuð par sem hún beinist aðallega að jöfnum rétti einstaklinga til aðgengis frekar en að leggja áherslu á gildi og inntak menntunar. Pá endurspeglar stefnan orðræðu nýsamlögunar (e. neo-assimilation) par sem áhersla er lögð á ábyrgð einstaklinga á eigin námi og framtíðarmöguleikum í gegnum val, virkni og íslenskufærni fremur en sampætta og samfélagslega nálgun. Orðræða kennara bar vott um aukið álag í starfi par sem peir „preifa sig áfram í myrkrinu“ og fá lítinn kerfislægan stuðning. Skortur á slíkum stuðningi sem og heildarstefnumótun gerði peim oft erfitt um vik að
\end{abstract}

\author{
Icelandic Review of Politics and Administration Vol 14, Issue 3 (183-204) \\ (c) 2018 Contacts: Eva Harđardóttir, evahar@hi.is \\ Article first published online December 13th 2018 on http://www.irpa.is \\ Publisher: Institute of Public Administration and Politics, Gimli, Sæmundargötu 1, 101 Reykjavík, Iceland \\ Stjórnmál \& stjórnsýsla 3. tbl. 14. árg. 2018 (183-204) Fræđigreinar \\ (C) 2018 Tengiliðir: Eva Harđardóttir, evahar@hi.is \\ Vefbirting 13. desember 2018 - Birtist á vefnum http://www.irpa.is \\ Útgefandi: Stofnun stjórnsýslufræða og stjórnmála, Gimli, Sæmundargötu 1, 101 Reykjavík \\ DOI: https://doi.org/10.13177/irpa.a.2018.14.3.2 \\ This work is licensed under a Creative Commons Attribution 3.0 License.
}


taka siðferðislega faglegar ákvarðanir og ögra viðteknum og stöðluðum hugmyndum um margbreytileika og menntun.

Efnisorð: Ungt flóttafólk; menntun; menntastefna; nýsamlögun; orðræðugreining.

\title{
„Moving in the dark": Exploring representations of refu- gee youth through Icelandic public policy documents and teachers narratives
}

\begin{abstract}
In spite of the fact that Iceland accepts fewer refugees then other European countries, the number of young refugees in Iceland has grown as a result of international and forced migration. While there is a growing body of Icelandic research on multicultural and inclusive education the focus has yet to concern itself with refugee youth and their educational or social challenges. Multiculturalism and matters of integration are increasingly being contested as refugee youth reception and education are perceived to be in a state of crisis. This study examined the forms of policy in place related to young refugees in Iceland and how it impacts their educational and social inclusion. Drawing on the field of critical education policy analysis, we analyzed official policy documents as well as narratives of fourteen lower and upper secondary teachers. Findings indicate that the current policies are limited in scope and emphasis equality on the basis of sameness and access to education rather than equity, social justice and quality of education. The policy, as it appears both in the form of texts and discourse, is shaped by neo-assimilative ideology that highlights individual responsibility for educational outcomes through choice policy, active participation and Icelandic language skills based on national discourse of inclusion. Teachers described themselves as "moving in the dark" without institutional policy guidance or support making it it difficult for them to make ethical and political choices that challenge the normative view of education and integration in what they describe as new and challenging situations.
\end{abstract}

Keywords: Refugee youth; education policy; neo-assimilation; discourse analysis.

\section{Inngangur}

Flóttamannahjálp Sameinuðu pjóðanna áætlar að börn og ungmenni séu nú ríflega helmingur alls flóttafólks í heiminum. Flest flýja stríðsátök eða ofsóknir og mörg hver ferðast án fylgdar (UNHCR 2017). Á Íslandi má greina pessa próun par sem pýði flóttafólks er ungt (Alpjóðamálastofnun Háskóla Íslands 2017; Kristín Erla Harðardóttir, Heiður Hrund Jónsdóttir \& Friðrik H. Jónsson 2005) og fleiri fylgdarlaus ungmenni koma hingað til lands en áður (Útlendingastofnun 2017). Flóttamannahjálp Sameinuðu pjóðanna skilgreinir ungmenni á aldrinum 15-24 ára sem mikilvægan hóp flóttafólks með parfir sem eru sérstakar og ólíkar pörfum bæði barna og fullorðinna (UNHCR 
2017). Hérlendis er ekki haldið utan um tölfræðilegar upplýsingar er varða pennan hóp en til að fá mynd af pví hversu margt ungt fólk sækir um og hlýtur alpjóðlega vernd á Íslandi má nefna að árið 2016 sóttu 249 börn undir 18 ára aldri um vernd en 64 hlutu dvalarleyfi pað ár (Hagstofan 2017; Útlendingastofnun 2017). Pá fengu 73 einstaklingar á aldrinum 18-34 ára dvalarleyfi sama ár (Hagstofan 2017). Óljóst er hvernig pessum hópi reiðir af innan félags- og menntakerfisins á Íslandi.

prátt fyrir ört stækkandi fræðasvið fjölmenningarlegrar menntunar (Hanna Ragnarsdóttir \& Elsa Sigríður Jónsdóttir 2010; Hanna Ragnarsdóttir, Elsa Sigríður Jónsdóttir \& Magnús Dorkell Bernharðsson 2007) og skóla án aðgreiningar (Dóra S. Bjarnason, Hermína Gunnpórsdóttir \& Ólafur Páll Jónsson 2016), hafa fáar rannsóknir hérlendis beint sjónum sínum að flóttafólki sérstaklega, högum peirra og reynslu. Enn færri hafa kannað veruleika eða reynslu ungs flóttafólks (Guðbjörg Ottósdóttir \& Helena Wolimbwa 2011). Fyrirliggjandi rannsóknir á fjölmenningarlegri menntun á Íslandi hafa hingað til lagt áherslu á að draga fram almenna og jákvæða pætti í aðlögunarferli nemenda (sjá t.d. Hanna Ragnarsdóttir 2016) frekar en að beina sjónum sínum að flóknu samspili stefnumótandi orðræðu og peim áskorunum sem ungir innflytjendur og flóttafólk á Íslandi mætir. Meginmarkmið pessarar rannsóknar er að kanna hvers konar stefna sé við lýði um ungt flóttafólk á Íslandi með tilliti til möguleika pess á menntun og félagslegri inngildingu (e. inclusion) í ljósi hnattrænna aðstæðna og félags-, efnhagslegra og pólitískra áhrifa. Rannsóknin, sem tilheyrir póststrúktúralískri hefð, er hluti af stærri rannsókn um ungt flóttafólk í íslensku samfélagi par sem sjónum er m.a. beint að hlutverki stefnumótunar á sviði félags- og menntamála í reynslu og upplifun ungs flóttafólks á menntun, próun borgaravitundar og pátttöku í íslensku samfélagi.

\section{Bakgrunnur}

\subsection{Menntastefnumótun í ljósi félags-, efnahagslegra og pólitískra áhrifa og staða ungs flóttafólks á Íslandi}

Óhætt er að fullyrða að hugmyndafræði nýfrjálshyggju hafi sett mark sitt á stefnumótun um heim allan frá pví á níunda áratug 20. aldar. Hugtakið snertir allt í senn, hugmyndir og aðgerðir sem birtast meðal annars á vettvangi mennta- og skólamála (Connell 2013). Hérlendis hefur verið fjallað um áhrif nýfrjálshyggju á menntun meðal annars í tengslum við aukna áherslu á markaðshyggju og skólaval (Berglind Rós Magnúsdóttir 2013; Ólafur Páll Jónsson 2014). Sem dæmi leggur menntastefna í anda nýfrjálshyggju áherslu á að neytendur (nemendur og foreldrar) hafi frelsi til að velja sér pjónustu (menntun) við hæfi og beri pá að sama skapi ríkari ábyrgð á vali sínu og árangri. Pannig er undirrót vandamála og misréttis gjarnan talin liggja hjá einstaklingum til dæmis foreldrum, nemendum eða kennurum og litið fram hjá kerfislægum, félagslegum og efnahagslegum páttum sem geta haft neikvæð áhrif á skólastarf (Berglind Rós Magnúsdóttir 2016). Rannsóknir hafa sýnt að í slíku kerfi upplifa kennarar aukið álag og kröfur um að mæta markmiðum um mælanlegan árangur frekar en að byggja á fagvitund sinni og raunverulegum kennsluaðstæðum (Connell 2013; Cribb \& Ball 2005). Íslenskir kennarar sem lýsa reynslu sinni af kennslu nemenda af erlendum uppruna telja sig til að mynda undir auknu álagi og ekki 
nægilega vel studda af skólayfirvöldum til að skilja eða koma til móts við væntingar og parfir nemenda sinna. Deir upplifa pannig lítið svigrúm til að veita pessum hópi nemenda nægilega fjölbreyttan stuðning (Hermína Gunnpórsdóttir, Stéphanie Barillé \& Markus Meckl 2017).

Önnur birtingarmynd nýfrjálshyggju er áhersla á útkomu og árangur á kostnað umræðu um inntak og gæði. Umræða um einstaklingshæfni og árangur tiltekinna hópa hefur verið ríkjandi par sem prófað er í páttum sem teljast vera mælikvarðar á samkeppnishæfi pjóða. Greina má pessa præði meðal annars í tengslum við pá reglulegu umræðu sem PISA niðurstöður fá hérlendis (Menntamálastofnun 2016) par sem rætt er um samkeppnishæfni íslenska menntakerfisins í tengslum við slaka frammistöðu nemenda af erlendum uppruna (Hulda Karen Daníelsdóttir \& Hulda Skogland 2018). Í samræmi við hugmyndafræði nýfrjálshyggjunnar er einnig lögð sífellt ríkari áhersla á að skólar marki sér ákveðna stefnu eða ímynd og laði að sér nemendur (Berglind Rós Magnúsdóttir 2016). Ímynd og hlutverk skólanna er nátengt pví hvers konar stöðu, fjármagns- og menningarauð nemendur sem sækja skólann búa yfir (Reay 2004; Thomson 2014). Í slíku umhverfi verður minni eftirspurn eftir tilteknum nemendahópum sem taldir eru skaða ímynd skólans í sívaxandi samkeppnisumhverfi. Færð hafa verið rök fyrir pví að slík próun ýti undir aðgreiningu og jaðarsetningu viðkvæmra hópa (Berglind Rós Magnúsdóttir 2016; Slee \& Allan 2001). Í Reykjavík má sjá skýr merki pess að íslenskir foreldrar velji sig í auknum mæli frá tilteknum hverfum og skólum sem leiðir til pess að til verða svæði með hlutfallslega mörgum nemendum af erlendum uppruna og nemendum sem glíma við krefjandi aðstæður af öðru tagi (Auður Magndís Auðardóttir \& Berglind Rós Magnúsdóttir 2018).

pessari próun svipar til peirra breytinga sem átt hafa sér stað á Norðurlöndunum og víðar. Í Svípjóð og Danmörku hefur til að mynda verið bent á að flótti innfæddra foreldra úr tilteknum hverfum og skólum hafi í för með sér alvarlegar afleiðingar í formi félagslegrar einangrunar og fordóma í garð ungmenna af erlendum uppruna (Dovemark o.fl. 2018; Rangvid 2010). Drátt fyrir að viðhorf til flóttafólks mælist jákvæð á Íslandi (Amnesty International 2016; Sigrún Ólafsdóttir 2018) virðast pau engu að síður bundin tilteknum skilyrðum. Pannig mælist til dæmis minnstur stuðningur við fólk frá Afríku og Mið-Austurlöndum (Maskína 2015) en paðan eiga flestir flóttamenn rætur sínar að rekja. Pá hefur Evrópunefnd gegn kynpáttafordómum og umburðarleysi (ECRI 2017) bent á að hatursorðræða gegn múslimum hafi aukist á undanförnum árum og að innflytjendur á Íslandi mæti margvíslegum kerfislægum hindrunum.

†ó ekki séu til opinberar upplýsingar um nemendur með flóttamannabakgrunn í íslenskum skólum er ljóst að nemendur af erlendum uppruna glíma frekar við námstengda erfiðleika en íslenskir nemendur og eiga frekar á hættu að hverfa frá námi (Stella Blöndal, Jón Torfi Jónasson \& Anne-Christine Tannhäuser 2011). Í könnun frá árinu 2005 á líðan ungs flóttafólks ${ }^{1}$ á Íslandi kom í ljós að ungmennin upplifðu meiri kvíða og vanlíðan gagnvart námi en íslenskir nemendur (Kristín Erla Harðardóttir o.fl. 2005). Nýlegar eigindlegar rannsóknir benda til pess að pau eigi erfitt með að tengjast íslenskum ungmennum (Gestur Guðmundsson 2013; Maja Loncar 2016) og upplifi skort á fjöl- 
menningarlegri menntun í skólakerfinu (Berglind Rós Karlsdóttir 2013). Đó greina megi aukna áherslu á fjölbreytileika og jafnan rétt nemenda til náms í íslenskri menntastefnu (Evrópumiðstöð um nám án aðgreiningar 2017) hefur umfjöllun um fjölmenningu og aðlögun innflytjenda verið takmörkuð (Ingólfur Ásgeir Jóhannesson 2007) og gjarnan einskorðuð við íslenskt tungumál og hefðir (Eva Harðardóttir 2010). Pessi nálgun hefur verið gagnrýnd fyrir að byggja á stöðluðum hugmyndum um menningu og skort á alpjóðlegri sýn (Brynja Halldórsdóttir, Berglind Rós Magnúsdóttir \& Ólafur Páll Jónsson 2016). Í næsta kafla verður fjallað nánar um mikilvægi sampætts (e. relational) skilnings á fjölmenningu og borgaravitund í mótun menntastefnu.

\section{2 Ólíkur skilningur á fjölmenningu og borgaravitund}

Í skrifum sínum um gildi hugtaksins fjölmenningarleg menntun greina Tarozzi og Torres (2016) ólíkan skilning á fjölmenningu í pólitískri og opinberri umræðu. Peir telja mikilvægt að gera greinarmun á stöðluðum skilningi á fjölmenningu annars vegar og sampættum skilningi hins vegar. Fræðikonan Jo-Anne Dillabough (2016) speglar pessar hugmyndir og leggur auk pess ríka áherslu á pólitískt og sögulegt samhengi ríkjandi menntastefnu í tengslum við félagslega inngildingu og menntun ungs flóttafólks. Í töflu 1 má sjá nokkur lykilhugtök sem sótt eru í skrif Tarozzi og Torres og Dillabough og varpa ljósi á ólíkan hugtakaskilning.

Tafla 1. Lykilhugtök sem endurspegla staðlađan eđa sampættan skilning á fjölmenningu og borgaravitund

\begin{tabular}{|c|c|c|}
\hline & $\begin{array}{l}\text { STAĐLAĐUR skilningur á fiölmenningu (e. } \\
\text { Normative multiculturalism) }\end{array}$ & $\begin{array}{l}\text { SAMPÆETTUR skilningur á fjölmenningu (e. } \\
\text { Constructive multiculturalism) }\end{array}$ \\
\hline \multirow[t]{2}{*}{$\begin{array}{l}\text { Menning } \\
\text { og tjáning }\end{array}$} & $\begin{array}{l}\text { Fjölbreytileiki skilinn út frá pví hvað skilur fólk } \\
\text { og hópa að (e. diversity as differences). }\end{array}$ & $\begin{array}{l}\text { Fjölbreytileiki settur í samhengi við ólíka } \\
\text { reynslu, upplifun og sjáfsmyndir einstaklinga. }\end{array}$ \\
\hline & $\begin{array}{l}\text { Megin áhersla á pjóđmenningu og færni } \\
\text { nemenda í pjóðtungu mótttökupjóðar. }\end{array}$ & $\begin{array}{l}\text { Tungumáliđ hluti af ađlögun en ríkari áhersla } \\
\text { á fjölbreytta reynslu og færni nemenda. }\end{array}$ \\
\hline Jafnrétti & $\begin{array}{l}\text { Jöfn tækifæri (e. equality of opportunities). } \\
\text { Jafnrétti greint út frá sömu réttindum ólíkra } \\
\text { einstaklinga t.d. ađgengi (e. access) að námi. }\end{array}$ & $\begin{array}{l}\text { Jafnræđi (e. equity). Jafnrétti byggt á félags- } \\
\text { legu réttlæti og möguleikum fólks til ađ skapa } \\
\text { sér rými og rödd. Áhersla á gæđi og inntak. }\end{array}$ \\
\hline \multirow{2}{*}{$\begin{array}{l}\text { Borgara- } \\
\text { vitund og } \\
\text { pátttaka }\end{array}$} & $\begin{array}{l}\text { Pjóđhverf borgaravitund (e. national citi- } \\
\text { zenship). }\end{array}$ & $\begin{array}{l}\text { Gagnrýnin og alpjóđleg borgaravitund (e. } \\
\text { global citizenship). }\end{array}$ \\
\hline & $\begin{array}{l}\text { Einstaklingsábyrgð (e. individual responsibi- } \\
\text { lity) á pátttöku og aðlögun. }\end{array}$ & $\begin{array}{l}\text { Samábyrgð (e. collective responsibility) á } \\
\text { pátttöku og ađlögun. }\end{array}$ \\
\hline
\end{tabular}

Heimild: Dillabough 2016; Tarozzi \& Torres 2016

Allt frá fyrstu lögum um almenningsfræðslu við upphaf 20. aldarinnar hefur jafnrétti verið eitt af meginmarkmiðum menntastefnu hér á landi. Orðasambandið „skóli án aðgreiningar" kom fyrst inn í opinbera umræðu með undirritun Salamanca-yfirlýsingarinnar árið 1994 en var bó ekki staðfest í lögum fyrr en árið 2008 (Grétar L. Marinósson 
\& Dóra S. Bjarnason 2016; Steingerður Ólafsdóttir o.fl. 2015). Í nútímaumræðu hefur jafnréttishugtakið próast frá pví að vísa til aðgengis að sömu tækifærum(e. equality as opportunities) yfir í hugmyndir um jafnræði (e. equity) par sem fléttast saman aðgerðir gegn misrétti og sampætting jafnréttis inn í heildarstefnumótun. Pannig á skóli án aðgreiningar í reynd að vera sáttmáli um réttlátt samfélag (Kristín Dýrfjörð, Pórður Kristinsson \& Berglind Rós Magnúsdóttir 2013; Ólafur Páll Jónsson 2011). Áhersla á réttlæti birtist einnig í skrifum Tarozzi og Torres (2016) sem benda á að jafnréttishugtakið verði ávallt að tengja við félagslegt réttlæti ólíkra samfélagshópa annars sé hætta á að pröng og stöðluð áhersla á jafnrétti breiði yfir raunverulegt og undirliggjandi misrétti gagnvart minnihlutahópum eins og Dillabough (2016) hefur fjallað um.

Sú aðgerð að veita minnihlutahóp sama rétt og meirihlutahóp tengist hugmyndum um samlögun (e. assimilation) par sem innflytjendur eru hvattir til að aðlaga sig аð ríkjandi félagslegum og menningarlegum siðum (Castells 2004). Í tengslum við menntun birtist pessi aðgerð meðal annars í pví að veita innflytjendum og flóttafólki jafnt aðgengi að námi á forsendum pess að pau læri ríkjandi tungumál. Rannsakendur hafa bent á að einsleit áhersla á kennslu og færni nemenda í tungumáli mótttökupjóðar geti leitt til pess að litið sé fram hjá annarri færni nemenda (Dudley-Marling 2010). Sem dæmi má nefna pegar rætt er um „mállausa“ nemendur í ljósi pess að peir tala ekki opinbert tungumál landsins. Slík umfjöllun er til pess fallin að ræna pau annarri ímynd en peirri sem markast af stöðu fórnarlambs eða einstaklings sem skortir ákjósanlega hæfni og stendur utan við hið viðtekna (e. normativity) í samfélaginu (Arnot \& Pinson 2005; Kristín Loftsdóttir 2018). Á Íslandi par sem pjóðararfurinn byggist á fámennu málsamfélagi hafa hugmyndir sem tengjast pjóðhverfri borgaravitund oft verið áberandi, bæði í kringum sjálfstæðisbaráttuna en einnig á seinni tímum, t.d. í hinu svonefnda sögukennsluskammdegi á 9. áratug 20. aldar (Ólafur Páll Jónsson 2018). Hinar pjóðhverfu áherslur birtast einnig í hreintungustefnu par sem nemendur sem töldust flámæltir voru aðgreindir frá öðrum til pess að „,smita“ ekki og spilla hreintungu annarra nemenda (Bergljót Baldursdóttir \& Ásgrímur Angantýsson 2012). Pá hafa rannsóknir sýnt að í ljósi pess hversu nátengt íslenska tungumálið er tilteknum pjóðararfi og menningu upplifa innflytjendur tungumálið gjarnan sem útilokandi eða óaðgengilegan pátt í aðlögunarferlinu (Unnur Dís Skaptadóttir \& Pamela Innes 2017).

Í heimi sem einkennist af hnattvæðingu, fólksflutningum og menningarlegum margbreytileika er mikilvægt að endurskoða viðteknar hugmyndir um borgaravitund og menningu. Fjölmargir fræðimenn hafa fjallað um mikilvægi menntunar í pessu tillit ${ }^{2}$. Ekki síst pegar hugmyndir um fjölmenningu eiga undir högg að sækja vegna aukinna áhrifa frá öfgaöflum sem berjast fyrir aðskilnaði og einangrun (European Union Agency of Fundamental Rights 2017). Í umfjöllun um alpjóðlega borgaravitund og menntun (e. global citizenship education) fjalla Tarozzi og Torres (2016) um mikilvægi pess að líta á fólksflutninga sem hluta af alpjóðlegu ferli sem snertir öll menntakerfi heims. Peir gagnrýna bæði Bandaríkin og Evrópu fyrir að meðhöndla flóttafólk sem einangrað vandamál og líta fram hjá grundvallaratriðum á borð við orðræðu um fjölmenningu og möguleika fólks til menntunar. Pá tengja peir bakslag í umræðu um fjölmenningu, par sem pjóð- 


\section{STJÓRNSÝSLA}

hverfur og staðbundinn skilningur á menningu og borgaravitund magnast upp, við áhrif nýfrjálshyggju. Detta samspil og orðræðan sem skapast í kjölfarið nefna peir nýsamlögun (e. neo-assimilation). Slík orðræða, eins og hún birtist í opinberri stefnumótun og á vettvangi menntunar, vekur upp spurningar um stöðu og möguleika ungs flóttafólks til félagslegrar aðlögunar og inngildingar í samfélög og menntakerfi. Nýnæmi peirrar rannsóknar sem hér er lýst felst m.a. í að kanna hvers konar stefna ríki um ungt flóttafólk á Íslandi og með hvaða hætti megi greina pá stefnu út frá alpjóðlegum og samfélagslegum áhrifum. Megin rannsóknarspurningin er: Hvers konar menntastefna er við lýdi um ungt flóttafólk á Íslandi? A) Hvernig markast hún af pólitískum og samfélagslegum áhrifum á borð við orðræðu nýsamlögunar? B) Hvernig telja kennarar að sú stefna sem er við lýði um menntun ungs flóttafólks móti starfsaðstæður peirra og kennslu?

\section{Aðferð}

Rannsóknin byggir á gagnrýnni menntastefnufræði (e. critical education policy studies) eða stefnufélagsfræði (e. policy sociology) (Ball 1997). Stephen Ball hefur gagnrýnt hefðbundnar menntastefnurannsóknir (e. policy science) par sem gefið er í skyn að menntastefnur orki alls staðar með svipuðum hætti; óháð staðsetningu, nemendasamsetningu eða menningarlegu og sögulegu samhengi. Petta gagnrýnir Ball (2015) og bendir á að rannsóknir á mótun menntastefnu purfi að tengja við alpjóðlega pólitíska menntaumræðu. Á peim grunni völdu höfundar að styðjast við aðferðir orðræðugreiningar í anda póststrúktúralískar hefðar (Foucault 2002) sem er algengt verklag við greiningu gagna í stefnufélagsfræði og byggir á að fólk leggi ólíkan skilning í hugtök á borð við pekkingu, frelsi og vald. Pannig hafa bæði textar og tungumál síbreytilega merkingu í hugum fólks og virkni í að skapa mismunandi ímyndir eða útgáfur af veruleikanum - háð félags- og menningarlegu samhengi (Ball 2015).

Í rannsókninni var farin sú leið að greina stefnumótandi orðræðu í fyrsta lagi eins og hún birtist á pólitískum vettvangi í opinberum stefnuskjölum um móttöku og aðlögun flóttafólks og í öðru lagi eins og hún birtist á vettvangi skólans sem orðræða og hugmyndir kennara og stjórnenda. Aðferðin byggir á peirri hugmynd að menntastefna birtist ekki eingöngu í textum (e. policy as text) sem túlka má á mismunandi hátt heldur einnig 1 orðræðu (e. policy as discourse) skólafólks sem endurskapar stefnuna með eigin túlkun, mótspyrnu eða sampykki (Ball, Maguire \& Braun 2012). Pá er mikilvægt að taka fram að orðræða og ríkjandi hugmyndafræði markast ekki eingöngu af pví sem stendur skrifað eða er sagt beinum orðum heldur einnig af pví sem látið er ósagt (sjá t.d. Ingólfur Ásgeir Jóhannesson 2013). Hið ósagða og skortur á umfjöllun er oftar en ekki pað sem mótar veruleika ungs flóttafólks og takmarkar möguleika peirra til menntunar (WRC \& UNCHR 2016).

\subsection{Val á gögnum og pátttakendur}

\subsubsection{Stefnuskjöl}

Til greiningar voru valin tvö opinber stefnuskjöl sem fjalla um móttöku og pjónustu við flóttafólk á Íslandi. 1) Viðmiðunarreglur flóttamannanefndar um móttöku og aðstoð við hópa 
flóttafólks sem hingað kemur í boði stjórnvalda, útgefið af Flóttamannanefnd árið 2013. 2) Leiðbeinandi reglur fyrir sveitarfélög um móttökupjónustu og aðstod við félagslega pátttöku flóttafólks sem hlotið hefur alpjóðlega vernd, útgefið af Velferðarráðuneytinu árið 2014. Við val á skjölunum var miðað við að pau hefðu til umfjöllunar málefni flóttafólks og að ábyrgðaraðilar væru pólitískir fulltrúar í slíkri stefnumótun.

Í ljós kom að hvorugt skjalið hefur lagalegt eða reglugerðarígildi prátt fyrir að innihalda lýsingar á pví hvernig standa skuli að menntun og félagslegri aðlögun ungs flóttafólk ${ }^{3}$. Í skjölunum er hins vegar stuðst við og vísað til fyrirliggjandi laga og reglugerða á borð við lög um grunn- og framhaldsskóla. Ákveðið var að nota pessi tilvísunarskjöl til stuðnings við greiningu aðalskjalanna (sjá töflu 2) en vísa í niðurstöðum og umræðum einungis til peirrar orðræðu sem fyrirfinnst í lykilstefnuskjölunum tveimur. Í öðrum hluta gagnasöfnunarinnar kom einnig í ljós að flestir kennaranna sem tóku pátt í rýnihópaviðtölunum pekktu til peirra lykilskjala sem valin voru til greiningar umfram önnur opinber stefnuskjöl svo sem lög um útlendinga, opinberar skýrslur, áætlanir, pingskjöl eða samantektir á málefnum flóttafólks ${ }^{4}$ Slík skjöl sem útgefin eru eftir árið 2014 vísa að jafnaði til peirra tveggja lykilskjala sem hér eru greind.

Tafla 2. Lykilstefnuskjöl og tilvísunarskjöl

\begin{tabular}{|c|c|c|c|}
\hline Stjórnsýsluleg stađa & Stefnuskjöl & Útgáfutími & Útgefandi \\
\hline \multicolumn{4}{|c|}{ Lykilstefnuskjöl } \\
\hline Viðmiðunarreglur & $\begin{array}{l}\text { Viðmiðunarreglur flótta- } \\
\text { mannanefndar um móttöku og } \\
\text { ađstoð við hópa flóttafólks }\end{array}$ & 2013 & $\begin{array}{l}\text { Flóttamannanefnd } \\
\text { skipuđ af félagsmála- } \\
\text { ráđherra }\end{array}$ \\
\hline Leiðbeinandi reglur & $\begin{array}{l}\text { Leiđbeinandi reglur fyrir sveit- } \\
\text { arfélög um mótttökupjónustu } \\
\text { og ađstoð við félagslega pátt- } \\
\text { töku flóttafólks }\end{array}$ & 2014 & Velferđarráđuneyti \\
\hline \multicolumn{4}{|c|}{ Tilvísunarskjöl } \\
\hline \multirow[t]{2}{*}{ Lög } & Lög um grunnskóla & 2008 & $\begin{array}{l}\text { Mennta- og menn- } \\
\text { ingarmálaráđuneyti }\end{array}$ \\
\hline & Lög um framhaldsskóla & 2008 & $\begin{array}{l}\text { Mennta- og menn- } \\
\text { ingarmálaráđuneyti }\end{array}$ \\
\hline \multirow[t]{2}{*}{ Reglugerđir } & $\begin{array}{l}\text { Reglugerð um nemendur með } \\
\text { sérparfir í grunnskólum }\end{array}$ & $\begin{array}{l}2010 \text { m. } \\
\text { breytingum } 2015\end{array}$ & $\begin{array}{l}\text { Mennta- og menn- } \\
\text { ingarmálaráđuneyti }\end{array}$ \\
\hline & $\begin{array}{l}\text { Reglugerđ um nemendur međ } \\
\text { annađ tungumál en íslensku í } \\
\text { framhaldsskóla }\end{array}$ & 2009 & $\begin{array}{l}\text { Mennta- og menn- } \\
\text { ingarmálaráđuneyti }\end{array}$ \\
\hline \multirow[t]{2}{*}{ Reglugerđarígildi } & Ađalnámskrá grunnskóla & 2011 og 2013 & $\begin{array}{l}\text { Mennta- og menn- } \\
\text { ingarmálaráđuneyti }\end{array}$ \\
\hline & Ađalnámskrá framhaldsskóla & 2011 & $\begin{array}{l}\text { Mennta- og menn- } \\
\text { ingarmálaráđuneyti }\end{array}$ \\
\hline
\end{tabular}


Eva Harðardóttir

Berglind Rós Magnúsdóttir
STJÓRNMÁL

STJÓRNSÝSLA

\subsubsection{Rýnihópaviðtöl}

Tekin voru fimm rýnihópaviðtöl við fjórtán kennara og stjórnendur úr tveimur grunnskólum og premur framhaldsskólum. Viðtölin við kennarana voru tekin upp og afrituð orðrétt í tölvu samdægurs. Viðtölin voru 60 til 90 mínútur að lengd hvert og fóru fram í skólum viðkomandi kennara par sem talað var við tvo til fjóra kennara samtímis. Markmiðið með pví að taka viðtöl við fleiri en einn kennara í einu var að leita eftir ríkjandi viðmiðum á tilteknum vettvangi frekar en einstaklingsmiðaðri reynslu. Á sama tíma og persónuleg dæmi frá einstaka kennurum studdu við niðurstöður voru pað ekki síður samræður og samskipti kennarana sem vörpuðu ljósi á ólíka orðræðu um ungt flóttafólk og menntun. Allir stjórnendurnir höfðu sinnt kennslu með ungu flóttafólki áður eða sinntu slíkri kennslu samhliða stjórnunarstörfum á peim tíma sem viðtölin voru tekin. Í niðurstöðum er pví rætt um alla viðmælendur sem kennara til einföldunar. Í töflu 3 má sjá hvernig pátttakendur skiptust eftir stöðu innan skólans, skólastigi, móttökuleið nemenda við skólann og hversu langa reynslu hver skóli hafði af pví að taka á móti nemendum með flóttamannabakgrunn.

Tafla 3. Skólastig, staðað viðmælanda, móttaka og reynsla

\begin{tabular}{lccccccc}
\hline Stofnun & \multicolumn{1}{c}{ Stjórnendur } & Kennarar & Samtals & Móttaka nemenda ígegnum: & Reynsla \\
\hline \multirow{2}{*}{ Grunnskóli } & A & 1 & 1 & 2 & Kvóta & 2 ár \\
\cline { 2 - 7 } & B & 1 & 2 & 3 & Kvóta og hæli & 10 ár \\
\hline \multirow{2}{*}{ Frambaldsskóli } & B & 1 & 1 & 2 & Kvóta og hæli & 10 ár \\
\cline { 2 - 7 } & C & 1 & 3 & 4 & Kvóta og hæli & 20 ár \\
\hline Samtals & & $\mathbf{5}$ & $\mathbf{9}$ & 14 & Kvóta & 2 ár \\
\hline
\end{tabular}

Einn grunnskóli og framhaldsskóli höfðu einungis tekið á móti flóttabörnum og ungmennum í gegnum svo kallað kvótaflóttakerfi með par til gerðum samningum á milli skóla og sveitarfélags á meðan aðrir unnu með nemendum sem komu bæði í gegnum kvótaflóttakerfið og í gegnum svo kallað hælisleitendakerfi ${ }^{5}$. Í umræðum um niðurstöður er eingöngu vísað til kennara út frá grunnskóla A eða B og framhaldsskóla A, B eða C. Ekki er gefin nánari lýsing á kennurum eða skólum til að tryggja nafnleynd og trúnað við pátttakendur.

\section{2 Úrvinnsla gagna og greining}

Greining gagna fór í upphafi fram með opinni kóðun par sem skjölin voru lesin í sitt hvoru lagi (Braun \& Clarke 2006). Í stefnuskjölunum var leitað eftir umfjöllun um ungt flóttafólk, menntun og félagslega aðlögun á meðan leitað var eftir skilningi og upplifun kennara af pessum páttum í hópviðtölunum. Næsta stig greiningar fól í sér lokaðri kóðun par sem gögnin voru lesin saman út frá rannsóknarspurningum (Braun \& Clarke 
2006; Ingólfur Ásgeir Jóhannesson 2013). Á pessu stigi var kóðunin dregin saman í pemu sem mynduðu prástef, endurtekningar eða mynstur í orðræðunni (Ingólfur Ásgeir Jóhannesson 2006a). Lokagreining og útfærsla á pemum tók einnig mið af kenningargunni greinarinnar (sjá töflu 2) sem unnin var í sameiningu í gegnum greiningarferlið af báðum höfundum. Við greiningu var lögð sérstök áhersla á að greina hvar, hvenær og í hvaða samhengi tiltekin orð og orðanotkun fékk rými og merkingu (Ball 2015). Pað er, hvað er talið vera eðlileg eða rétt lýsing á ungu flóttafólki á Íslandi, aðstæðum peirra og möguleikum.

\section{Niðurstöður og umræður}

Við greiningu á skjölunum var ljóst að ákveðin pögn ríkir um viðfangsefnið par sem erfitt reyndist að finna umfjöllun um ungt flóttafólk og menntun með beinum hætti. Dannig er til að mynda aldrei minnst á ungt flóttafólk sérstaklega í öllum peim tilvísunarskjölum (lögum, reglugerðum eða námskrám) sem pó er vísað til í lykilskjölunum sem greind voru. Dessar niðurstöður komu pó höfundum ekki sérlega á óvart par sem pær staðfesta niðurstöður og umfjöllun erlendra fræðimanna um hversu takmarkað rými ungt flóttafólk fær í stefnumótandi orðræðu (Dillabough 2016; WRC \& UNCHR 2016). Hins vegar kom á óvart hversu ólík og oft á tíðum mótsagnarkennd orðræða tekst á innan stefnuskjalanna og 1 frásögnum kennara. Fyrstu prjú pemun sem greint er frá eiga við pá orðræðu sem greina mátti pvert á gögnin á meðan fjórða pemað endurspeglar pað prástef sem ríkti í orðræðu kennara um áskoranir í starfi.

\subsection{Ađgengi og jafn réttur}

Í stefnuskjölunum jafnt sem í orðræðu kennara mátti greina skýra áherslu á að ungt flóttafólk hefði sama rétt til menntunar og íslensk ungmenni. Umræðan um jafnan rétt til náms tengdist nær eingöngu hugmyndum um aðgengi að skóla eða tiltekinni menntastofnun. Afar takmarkaða umfjöllun var að finna um gildi, inntak eða gæði menntunar fyrir ungt flóttafólk á Íslandi. Sem dæmi vísa stefnuskjölin með almennum hætti í lög um skólaskyldu barna annars vegar og fræðsluskyldu ungs fólks hins vegar (Lög um framhaldsskóla nr. 92/2008; Lög um grunnskóla nr. 91/2008) pegar fjallað er um rétt flóttabarna og ungmenna til náms. Í lögum um grunn- og framhaldsskóla er hins vegar hvergi minnst á flóttafólk né fjallað um aðgerðir sem miða að menntun og mótttöku nemenda með flóttamannabakgrunn.

Dar sem bæði stefnuskjölin eru ætluð sveitarfélögum vegna móttöku flóttafólks er eðlilegt að vænta umfjöllunar um hlutverk og skyldur lykilstofnanna og starfsfólks í pví ferli. Slíka umfjöllun er vart að finna í skjölunum að undanskilinni málsgrein par sem tekið er fram að skólastjóra beri að samræma aðgerðir „vegna málefna einstakra nemenda eftir poí sem purfa pykikr“" (Leiðbeinandi reglur, 8. grein, bls. 9) með tilvísun í reglugerð um nemendur með sérparfir (nr. 148/2015). Staða ungs flóttafólks er pannig hvorki skilgreind í sögulegu eða félagslegu samhengi og aðgerðir ætlaðar hópnum frekar tengdar við sérparfir og vandamál einstakra nemenda. Með slíkri umfjöllun er ýtt undir pá hugmynd að menningarlegur margbreytileiki og flóttamannabakgrunnur nemenda sé sér- 
stakt og einangrað vandamál eða frávik (Slee \& Allan 2001) en ekki eðlilegur hluti af nútíma skólasamfélagi (Tarozzi \& Torres 2016). Gengið er út frá pví að aðgengi að skóla eða menntastofnun tryggi ungu flóttafólki rétt til náms enda hafi pau pá sömu tækifæri til menntunar og íslensk ungmenni. Pessi efnistök eru óneitanlega í anda pess skilnings á jafnrétti sem Dillabough (2016) varar við, p.e. að minnihlutahópur hafi sama rétt (e. equality of sameness) og meirihlutahópur án pess að hyggja að stöðu eða möguleikum minnihlutahópsins til að fullnýta pennan rétt. Hætt er við pví að slík nálgun viðhaldi valdastöðu ákveðinna hópa og ýti öðrum valdaminni hópum líkt og ungu flóttafólki út á jaðarinn á vettvangi skólans.

Í orðræðu kennara mátti greina svipað prástef par sem sjaldan var minnst á sértækar aðgerðir eða sampættar breytingar á stefnumótun í anda jafnræðis (e. equity). Kennarar vísuðu hins vegar gjarnan til sömu laga og reglna og gert var í stefnuskjölunum til að undirstrika jafnan rétt allra nemenda: ,Ja, við förum auðvitað bara eftir námskerá pannig að við kennum bara sama efni en vid förum kannski ekeki jafn djúpt i pad... en pau fá bara sama efni og adrir nemendur" (Kennari i framhaldsskóla A). Hér birtist hugmyndin um jafnan rétt út frá viðteknum skilningi um jöfn tækifæri (e. equality of opportunities) á kostnað umræðu um inntak og gildi náms. Pá er ekki hugað að pví að ungt flóttafólk býr að jafnaði við færri bjargir til að nýta sér samskonar tækifæri og aðrir hópar í samfélaginu. Áherslan á flóttabörn og ungmenni sem einstaklinga (e. individual equality) innan skólans virtist ríkjandi í hugum kennara prátt fyrir meðvitund peirra um sérstöðu hópsins:

Detta eru fyrst og fremst bara nemendur sem er að koma í skólann okkar. Fyrst og fremst reynum við bara að hugsa að petta séu börn að koma í skólann og pannig tökum við peim. En auðvitað er maður sjálfur extra meðvitaður um aðstæður peirra (Kennari í grunnskóla A).

Hér skarast viðtekin orðræða um einstaklingsmiðað nám, sem sett hefur mark sitt á íslenska menntastefnumótun (Ingólfur Ásgeir Jóhannesson 2006b), við meðvitund kennarans um sérstakar aðstæður hópsins og pví ljóst að um ákveðna togstreitu er að ræða. Pannig tengdust flestar hugmyndir kennaranna um menntun ungs flóttafólks möguleikum og tækifærum peirra til að ná árangri sem einstaklingar frekar en spurningum um stöðu hópsins innan ríkjandi kerfis eða réttmæti pess á sama tíma og kennarar sýndu stöðu hópsins persónulegan skilning

\subsection{Einstaklingsval og ábyrgð? Kerfislægar hindranir, pvingað val og útilokun}

Í gögnunum kom fram að náms- og skólaval ungs flóttafólks á Íslandi er takmarkað á margan hátt. Í Viðmiðunarreglum Flóttamannanefndar segir: „Ungmenni, allt að 24 ára aldri, sem eru flóttafólk skulu fá námstilbod vid hafi i frambaldsskóla i ad minnsta kosti eitt ár" (Viðmiðunarreglur, 19. grein, bls. 5). Ekki er minnst á sambærileg tilboð í Leiðbeinandi reglum fyrir sveitarfélög sem gefur til kynna að sá hópur ungmenna sem hlotið hefur alpjóðlega vernd hérlendis njóti ekki slíkra tækifæra. Á undanförnum árum hefur pessi tiltekni hópur ungmenna farið ört stækkandi (Útlendingastofnun 2017) með tilheyrandi 
aðsókn í nám á framhaldsskólastigi. Í pessu samhengi lýstu tveir kennarar áhyggjum sínum af pví að mörgum nemendum eldri en 18 ára væri vísað frá námi vegna forgangs yngri nemenda (16-18 ára).

Баð eru samt alltaf færri og færri [eldri en 18 ára] sem komast að, aðsóknin er alltaf að aukast og við purfum að vísa frá nánast öllum sem eru komnir yfir tvítugt. Við getum náttúrlega ekki neitað neinum sem er á námsskyldualdri (Kennari i framhaldsskóla B).

Ég hef líka áhyggjur af eldri en samt ungum nemendum [18-24 ára] sem við erum að vísa meira og meira í önnur íslenskunámskeið... En hér er petta ekki bara stakt íslenskunámskeið - petta er skóli og pau purfa pað (Kennari í framhaldsskóla B).

Að pessu leyti hafa nemendur eldri en 18 ára ekki raunverulegt val um að sækja framhaldsskóla og njóta góðs af pví að vera í heildstæðu skólasamfélagi sem rekið er af ríkinu heldur er peim vísað á námskeið í framhaldsfræðslugeiranum sem fjármagnar sitt starf að talsverðu leyti með námskeiðsgjöldum. Yngri ungmenni eiga rétt á aðgengi samkvæmt fræðsluskyldulögum en hafa í fæstum tilvikum val um skóla í ljósi pess að framhaldsskólum á Íslandi er heimilt að setja sín eigin skilyrði fyrir inngöngu eins og einn kennaranna lýsti:

Sko eins og hjá okkur pá miðum við bara við að nemendur hafi grunn í íslensku, séu kannski búnir að vera tvö ár í grunnskóla eða búnir að taka sem samsvarar tveggja ára námi... [í íslensku] (Kennari í framhaldsskóla A).

Fleiri framhaldsskólar á landinu setja viðlíka eða strangari kröfur en pær sem hér er lýst og pví ljóst að ungt flóttafólk fellur ekki auðveldlega inn í pann hóp nemenda sem flestir framhaldsskólar sækjast eftir. Af lýsingu kennaranna í rannsókninni að dæma parf ungt flóttafólk helst að vera á aldrinum 16-18 ára auk pess að búa yfir talsverðri færni í íslensku til að eiga möguleika á inngöngu í framhaldsskóla en slíkt krefst bæði tíma og peninga sem flóttafólk hefur að jafnaði minna af en aðrir samfélagshópar (Alpjóðamálastofnun 2017; WRC \& UNCHR 2016). Hér endurspeglast hvernig íslenskt menntakerfi grundvallast á valfrelsi byggt á samkeppni um „hæfa“ nemendur sem leiðir af sér aðgreiningu og missrétti fyrir ungt flóttafólk hér á landi.

Algengt er að álagið við að sinna „sérstökum“ (Slee \& Allan 2001) nemendahópum dreifist ekki jafnt á skóla og kennara (Gewirtz o.fl. 2009) en slíkar hugleiðingar birtust skýrt í orðum kennaranna pegar rætt var um aukna aðsókn ungs flóttafólks í nám. Kennari við framhaldsskóla sem tekur hlutfallslega á móti fleiri nemendum með flóttamannabakgrunn en aðrir skólar sagði: 
Í okkar skóla finnum við alveg fyrir pví [aukinni aðsókn flóttafólks]. раð er mjög oft sagt bara ykkar skóli getur alveg sérhæft sig og tekið við pessum nemendum. En við purfum líka að passa okkur á pví að [pað] er mjög erfitt fyrir kennara að vera með marga í sínum hópi sem skilja illa íslensku... pannig að pað purfa bara fleiri skólar að taka pátt í pessu verkefni líka (Kennari i framhaldsskóla A).

Niðurstöður rannsókna sem sýna fram á veika náms- og félagsstöðu nemenda af erlendum uppruna hérlendis (Anh-Dao 2015; Kristín Erla Harðardóttir o.fl. 2005; Maja Loncar 2016; Stella Blöndal o.fl. 2011) benda til að vandamálið sé kerfislægt fremur en bundið við einstaka nemendur og færni peirra. Sérhæfing skóla er orðin meiri en áður og ákveðnir skólar pví opnari fyrir nemendahópum sem búa við krefjandi aðstæður á meðan aðrir skólar hafa fengið pað hlutverk að mennta einsleitari hópa sem falla betur að viðmiðum kerfisins (Ásgerður Bergsdóttir \& Berglind Rós Magnúsdóttir 2018; Berglind Rós Magnúsdóttir \& Unnur Edda Garðarsdóttir 2018). Ungt flóttafólk sem á pess ekki kost að ná slíkum viðmiðum, prátt fyrir ákvæði í reglum um jafnan rétt, er hættara við að lenda ekki eingöngu utan við skólakerfið sjálft heldur einnig á jaðri pess samfélags sem viðheldur viðteknum hugmyndum um gildi og virði einstaklinga og hópa. Próun í pá átt getur haft alvarlegar félagslegar afleiðingar í för með sér fyrir ungt flóttafólk eins og dæmi benda til á Norðurlöndunum (Dovemark o.fl. 2018; Rangvid 2010) og víðar (Dillabough 2016).

\subsection{Aðlögun og aðgreining - bjóðhverf borgaravitund}

Greina mátti ríkjandi hugmyndir um menningu sem einsleitt og stöðugt fyrirbæri í stefnuskjölum jafnt sem orðræðu kennara. Sem dæmi má nefna orðalag markmiða í skjölunum sem leggja áherslu á „ad tryggja árangursrika adlögun [flóttafólles] ad islensku samfélagi" (Leiðbeinandi reglur, 2. grein, bls. 1). og að „aðlaga flóttafólk... að islenskum aðstaðим“" (Viðmiðunarreglur, 14. grein, bls. 4). Hugtakið aðlögun birtist fyrst og fremst 1 í formi aðgerða sem snúa að pví að flóttafólk aðlagist íslenskum aðstæðum og samfélagi án gagnkvæmrar pátttöku eða aðlögunar íslensks samfélags og stofnanna. Hér má greina hugmyndafræði samlögunar (Castells 2004) par sem flóttafólk stendur utan við íslenska menningu og samfélag. Pá má einnig greina áherslu á einstakling og ábyrgð í anda orðræðu nýfrjálshyggju (Berglind Rós Magnúsdóttir 2016) par sem vísað er til árangursríkrar aðlögunar og pannig gefið í skyn að aðlögun flóttafólks sé mælanleg stærð í anda samkeppnis- og markaðslögmála.

Skýrar línur eru dregnar milli íslenskrar menningar annars vegar og menningar flóttafólks hins vegar meðal annars í Viðmiðunarreglum Flóttamannanefndar par sem segir: „Leitast skeal við à gefa flóttafólki kost á að verð̃a virkir pátttakendur i islensku samfélagi, en jafnframt virða rétt peirra til að vernda og rakta eigin menningu" (Viðmiðunarreglur, 14. grein, bls. 4). Dessi aðgreining menningarheima birtist 1 einsleitum skilningi á fjölbreytileika par sem hópar eru skilgreindir á grundvelli trúar, menningar eða pjóðernis (e. diversity as differences). Pannig spegluðu ákveðnar hugmyndir í máli kennara svipaða áherslu á 
flóttafólk sem aðgreindan hóp utan við viðtekna (Arnot \& Pinson 2005) og íslenska menningu:

Ég sé reyndar alltaf betur og betur að pau sem eru að læra íslensku sem annað tungumál að pau [ættu að] halda sinni menningu og tungumáli og hafa pað sem hornstein í sínu lífi (Kennari í framhaldsskóla A).

Prátt fyrir pá jákvæðu merkingu sem leggja má í orð kennarans um mikilvægi móðurmáls og menningar fyrir ungt flóttafólk er engu að síður gerður skýr greinamunur á menningu peirra sem pau eiga að hafa í sínu lifi annars vegar og íslenskrar menningar hins vegar. Svipað orðalag má finna í markmiðagrein í Viðmiðunarreglum Flóttamannanefndar pegar rætt er um nauðsyn pess að „vernda og rakta“ menningu flóttafólks en slík orðræða hefur verið tengd við úreltar hugmyndir í anda nýlendustefnu par sem vald meirihlutahópsins yfir minnihlutahópnum er tryggt og endurskapað með tilvísun í sérstöðu meirihlutahópsins sem umber og verndar viðkvæmari hóp (Kristín Loftsdóttir 2012, 2018). Wendy Brown (2008) hefur fjallað um hugtakið umburðarlyndi eins og pað birtist sem pólitísk lausn í félags- og menntastefnumótun í tengslum við fjölmenningu. Hún segir hugtakið péttofið markaðsvæddri hugmyndafræði og nýlendustefnu sem birtist meðal annars í pví að ríkjandi valdhafar skilgreini út frá hvaða færni eða árangursviðmiðum beri að sýna jaðarhópum á borð við flóttafólki umburðarlyndi. Greina mátti pessa einsleitu nálgun víða í gögnunum í samhengi við áherslu á íslenskukunnáttu sem forsendu fyrir námi og samfélagslegri pátttöku. Í pessu samhengi virðast reynsla og bakgrunnur ungs flóttafólks fá lítið sem ekkert vægi i skólasamfélaginu (Dudley-Marling 2010; Arnot \& Pinson 2005).

pjóðhverf viðhorf til borgaravitundar og pátttöku nemenda í íslensku samfélagi endurspegluðust einnig í orðræðu kennara um „mállaus börn“ eða „börn með ekkert tungumál“. Pannig lýsti einn framhaldsskólakennari pví að: „erfiðustu tilfellin eru peir nemendur sem hafa ekeki tungumál og pad er svo dapurt... pau eru bara á einskins manns landi" (Kennari í framhaldsskóla A). Đá lýstu flestir kennaranna starfi sínu með ungu flóttafólki fyrst og fremst út frá peirri ábyrgð að kenna peim íslensku.

Við erum á öllum stigum bara að kenna peim íslensku... smám saman síðan að koma inn upplýsingum um íslenskt samfélag... stundum er рað í tímum en stundum bara í frímínútum eða eftir tíma (Kennari í framhaldsskóla B).

Í takt við pessa ábyrgð lögðu kennararnir mikla áherslu á íslenskukennslu og færni nemenda sinna en nefndu pó öll aðra mikilvæga pætti í aðlögunarferlinu svo sem menningarog samfélagsfræðslu. Slík fræðsla var hins vegar sjaldan skilgreind sem hluti af móttöku og kennslu og pví oft óljóst hvernig hún ætti að fara fram eins og greina mátti í orðum eins grunnskólakennarans: 
Sko petta var nefnilega soldið trikkí. Fyrst litu peir svo á, nýbúakennararnir semsagt, að peir væru bara að fara kenna fyrstu skrefin í íslensku og síðan íslensku sem annað tungumál en svo datt bara allt í einu samfélagsfræðsla einhvernveginn á peirra herðar án pess að pað hafi verið rætt nokkuð... Peir voru bara að undirbúa sig undir að kenna tungumálið (Kennari í grunnskóla A).

Ljóst var að umfang peirrar kennslu sem tengdist ungu flóttafólki reyndist oft vera annað en gert var formlegt ráð fyrir. Allir kennararnir í rannsókninni höfðu sinnt pví sem mætti tengja við félags- og menningarlega pætti aðlögunar utan hefðbundinnar kennslu til dæmis í frímínútum eða í lok skóladags enda fundu peir pessum páttum ekki stað innan ríkjandi menntakerfis og skipulags (Connell 2013). Dannig leikur enginn vafi á pví að kennarar gera sér grein fyrir fjölbreyttum pörfum ungs flóttafólks innan íslensks menntakerfis og leggja á sig mikla vinnu til að mæta pessum pörfum. Hins vegar virðist skortur á opinberri stefnu og stuðningi til að leggja áherslu á aðra pætti en íslenskukennslu takmarka ráð peirra og rými til að sporna gegn viðteknum og pjóðhverfum viðmiðum um gildi og markmið menntunar (Tarozzi \& Torres 2016).

\section{4 Áhrif stefnu og ríkjandi strauma á starfsaðstæður að mati kennara}

Óhætt er að segja að orðræða nýsamlögunar (Tarozzi \& Torres 2016) birtist pvert á gögnin með áherslu á að ungt flóttafólk hafi sama rétt (e. equality as sameness) og íslenskir nemendur til aðgengis að námi og menntun. Inn í pessa orðræðu fléttast einnig pjóðhverfar hugmyndir um borgaravitund í gegnum pá kröfu að nemendur öðlist færni í íslensku tungumáli til að eiga möguleika á menntun og félagslegri pátttöku. Á sama tíma fjölluðu allir kennararnir í rannsókninni um mikilvægi og sérstöðu ungs flóttafólks auk pess sem mörg tóku persónulega ábyrgð á pví að koma til móts við fjölbreyttar parfir og áherslur í aðlögunarferli nemenda sinna umfram íslenskukennslu. Í pessu mótsagnakennda samhengi pótti mikilvægt að kanna hvaða áskoranir kennarar upplifðu í starfi sínu enda ræddu pau flest um stefnuleysi og skort á pólitískum stuðningi eins og einn grunnskólakennarinn komst að orði:

Stærsta hindrunin er náttúrlega sú að pað er engin stefnumótun í pessum málaflokki og við sem erum alltaf að vinna og vinna við náum ekki eyrum peirra sem hafa bæði peninga og völd. Бað eru ekki settir peningar í málaflokkinn í heild sinni. Kennarar hafa ekki aðstoð og fá ekki sérstakan undirbúning. Ég skynja pað bara pannig að í pólitíkinni er bara enginn áhugi á að taka heildstætt á pessum málum (Kennari í grunnskóla B).

Kennarar bentu margir á að hér væri um að ræða nýjar og vandasamar aðstæður sem peir væru ekki nægilega undirbúnir fyrir og pví ekki alltaf vissir um réttmæti ákvarðana sinna eins og einn framhaldsskólakennarinn lýsti: „Detta var bara nýr blutur og ég purfti að 
svara fyrir petta og ýmsar spurningar sem ég gat oft ek.ki svarad pvi skólinn var ek.ki med stefnu i neinum svona málum." Annar kennari við sama skóla sagði jafnframt: „Okekur er tíðratt um að parna sé hópur sem purfi ad hlúa betur ad en vid preifum okekur i raun áfram i myrkrinu“. Túlka má myrkrið í orðum kennarans sem pögnina sem ríkir í opinberri menntastefnu um ungt flóttafólk. Pögn sem ýtir undir óöryggi kennara og stjórnenda til að takast á við nýjar og krefjandi kringumstæður á grundvelli eigin siðferðis og reynslu eins og einn framhaldsskólakennarinn lýsti:

Mér finnst kannski aðallega vandamál hér að ekki skuli vera tekið tillit til pess að við erum með allt annan hóp en Íslendinga... Um daginn vantaði til dæmis alla múslimana af pví að pað var sérstakur dagur og pá spurði ég hvort við mættum gefa peim frí en við máttum pað ekki vegna pess að við værum á Íslandi og hér giltu íslenskar reglur (Kennari í framhaldsskóla B).

Hér stangast siðferðisviðmið kennara um hvað sé rétt að gera á við skólareglur sem lúta pjóðhverfum viðmiðum um rétt og möguleika fólks til pátttöku í skólasamfélaginu.

Heimspekingurinn Hannah Arendt (2005) hefur bent á mikilvægi bess sem hún kallar hið pólítíska loforð (e. the promise of politics) pegar samfélagslegar breytingar krefja fólk til afstöðu og aðgerða. Hið pólitíska loforð felur í sér möguleika fólks til að taka siðferðislegar og pólitískar ákvarðanir í krefjandi aðstæðum eins og peim sem nú hafa skapast með auknum menningarlegum margbreytileika í kjölfar fólksflutninga og hnattrænna breytinga. Pá skiptir máli að geta framfylgt gildum og aðgerðum sem markast ekki eingöngu af viðteknum hugmyndum og ríkjandi orðræðu heldur grundvallast á fjölbreytileika og reynslu allra peirra sem í aðstæðunum eru. Slíkt er til marks um raunverulega réttlátt kerfi. Фað kerfi sem kennararnir í rannsókninni lýstu endurspeglaði ekki pessa sýn eins og greina má í orðum eins grunnskólakennara sem upplifði mikinn mótstraum í starfi sínu:

Баð versta finnst mér er að vinna ekki með neitt bakland. Баð er rosalega ópægilegt. Við erum einhvern veginn alltaf að vinna á móti straumnum. Svo er bara alltaf minni og minni úthlutun [fjármagn], færra starfsfólk og færri tímar. Раð versta er síðan að раð er engin pekking á bak við stefnumótunarbreytingar eða ákvarðanir... (Kennari í grunnskóla B).

Prátt fyrir mótlætið voru dæmi um að kennarar næðu að taka skref í átt að sampættum skilningi á aðstæðum ungs flóttafólks og hlutverki menntunar í pví samhengi. Slík áhersla birtist sérstaklega í máli kennara sem töluðu um flóttafólk og menntun út frá mannúðarog réttlætissjónarmiðum frekar en viðmiðum um jafnan rétt einstaklinga eða tiltekinni færni. Hið alpjóðlega og sampætta sjónarhorn naut sín vel í máli eins framhaldsskólakennara pegar hann sagði: 


\section{STJÓRNMÁL \& \\ STJÓRNSÝSLA}

Ég sé petta fyrir mér pannig að við verðum bara og purfum að undirbúa bæði íslenska og aðflutta nemendur undir pann veruleika sem blasir við í Evrópu og öllum heiminum... semsagt pessi miklu fólksflutningar. Dessi veruleiki hefur alltaf verið til staðar en er núna að virkilega minna á sig og pá purfum við bara að bregðast við. Нvað ætlum við að gera? (Kennari í framhaldsskóla C).

Hér er lögð áhersla á að íslenskir nemendur séu mikilvægur hluti af alpjóðlegum breytingum og purfi viðeigandi undirbúning til jafns við pá nemendur sem flytjast hingað sökum fólksflutninga. Orð kennarans endurspegla pólitíska og faglega ábyrgð í anda pess pólitíska loforsð sem Arendt (2005) fjallar um og felst í pví að viðurkenna sögulegt samhengi hluta og sporna gegn viðteknum gildum og fyrirfram gefnum hugmyndun með aukið réttlæti ólíkra samfélagshópa að leiðarljósi.

\section{Samantekt og lokaorð}

Titill greinarinnar, „Að preifa sig áfram í myrkrinu“, er tilvitnun 1 orð kennara í rannsókninni og varpar skýru ljósi á meginniðurstöður hennar. Rannsóknarspurningin var einföld par sem spurt var hvers konar stefna er við lýði um ungt flóttafólk á Íslandi og hvernig slík stefna markast af hnattrænum, pólitískum og samfélagslegum áhrifum. Pá var einnig spurt að pví hvernig kennarar upplifa eigið starf og starfsaðstæður í tengslum við ríkjandi stefnu. Óhætt er að segja að hér á landi sé engin stefna við lýði um ungt flóttafólk. Umræða um ungt flóttafólk, menntun og félagslega inngildingu er afar takmörkuð og byggir helst á aðgreiningu par sem lagt er til að unnið sé með málefni ungs flóttafólks á grundvelli einstakra nemenda sem glíma við námsörðugleika eða sérparfir. pessi aðgreining skilgreinir menningarlegan margbreytileika og flóttafólk sem staðbundið vandamál og frávik í íslensku skólastarfi í stað pess að byggja á hnattrænum, uppbyggilegum og sampættum skilningi (Dillabough 2016; Tarozzi \& Torres 2016). Samspilið á milli stefnuskjalanna og peirra hugmynda sem kennararnir höfðu um ungt flóttafólk og menntun varpar áhugaverðu ljósi á áhrif nýsamlögunar (Tarozzi \& Torres 2016) á stefnumótandi orðræðu á Íslandi. Bar birtist með skýrum hætti áherslan á jafnan rétt og val einstaklinga, sem og ábyrgð á eigin námi og árangri í anda nýfrjálshyggju (Berglind Rós Magnúsdóttir 2015) sem blandast viðteknum og staðbundnum hugmyndum um fjölmenningu og margbreytileika. Detta samspil leiðir til pess að inngilding ungs flóttafólks 1 íslenskt menntakerfi og samfélag verður umfram annað háð pjóðhverfum forsendum (Brown 2008) sem birtast meðal annars í einsleitri áherslu á íslenskukennslu og færni nemenda.

Auðvelt er að halda pví fram að ungt flóttafólk á Íslandi hafi sama rétt til menntunar og íslenskir nemendur í ljósi pess að vísað er með skýrum hætti í réttinn til náms á grundvelli íslenskra laga um grunn- og framhaldsskóla auk pess sem kennarar minntust alloft á að ungt flóttafólk hefði rétt á og fengi sömu tækifæri til aðgengis að námi og kennslu og íslenskir nemendur. Sú skilgreining sem lögð er í hugtakið jafnrétti í dag felur hins vegar í sér tengsl við réttlæti og sampætt inngrip (Kristín Dýrfjörð, Dórður 
Kristinsson \& Berglind Rós Magnúsdóttir 2013; Ólafur Páll Jónsson 2011) frekar en að veita tilteknum hópi sömu réttindi og öðrum hópum (e. equality as sameness). Par sem jafnrétti birtist einungis í formi aðgengis að námi og án tengsla við hugtök á borð við félagslegt réttlæti og jöfnuð (Dillabough 2016) er hætta á að ungt flóttafólk á Íslandi upplifi miklar áskoranir og misrétti innan kerfisins. Pá tengist áherslan á að veita minnihlutahópi sömu tækifæri og ríkjandi meirihlutahóp einnig hugmyndum um samlögun (Castells 2004) par sem ætlast er til að minnihlutahópur lagi sig að fyrirliggjandi kerfi, stöðlum og viðmiðum. Fyrir ungt flóttafólk á Íslandi liggur fyrir að aðlaga sig að íslensku menntakerfi sem leggur ofuráherslu á færni peirra í íslensku án pess að taka til greina aðra mikilvæga færni og reynslu sem ungt flóttafólk hefur (Dudley-Marling 2010) og skiptir íslenskt samfélag máli.

Vegna áhrifa nýfrjálshyggju á íslenska menntastefnu m.a. í gegnum aukið skólaval og einstaklingsábyrgð (Berglind Rós Magnúsdóttir 2015) er ljóst að ungt flóttafólk býr ekki við sama val og íslensk ungmenni. Fæst peirra uppfylla pau skilyrði sem íslenskir framhaldsskólar setja eða leggja áherslu á í samkeppni sinni um nemendur. Slík skilyrði byggja á viðteknum hugmyndum um æskilegan félgs-, menningar og efnahagsauð s.s. hugmyndum um mælanlegan námsárangur og íslenskukunnáttu. Núverandi kerfi felur pannig í sér menningarlega aðgreiningu par sem einungis ákveðnir hópar samfélagsins búa við hreyfanleika og val (Auður Magndís Auðardóttir \& Berglind Rós Magnúsdóttir 2018). Aðrir eru bundnari af tilteknum búsetuúrræðum, skólum og námskeiðum sem bjóðast og er pannig ýtt enn frekar út á jaðarinn hvað varðar möguleika til menntunar og félagslegrar aðlögunar (Dillabough 2016).

Á sama tíma og stefnuskjöl og orðræða kennara mótaðist greinilega af áhrifum nýsamlögunar (Tarozzi \& Torres 2016) var ljóst að kennarar gerðu sér persónulega grein fyrir sérstakri stöðu ungs flóttafólks á Íslandi og öxluðu oft á tíðum mikla ábyrgð á pví að koma til móts við ólíkar parfir nemenda sinna utan hefðbundinnar kennslu og skólatíma. Pessi mótsagnarkennda og ólíka orðræða leiðir í ljós að kennarar eru staðsettir innan kerfis sem hvorki styður pá né styrkir til siðferðislegra og pólitískra aðgerða (Cribb \& Ball 2005) í nýjum og krefjandi aðstæðum. Aðstæðum sem kalla nú skýrar en nokkurn tíman áður eftir ákveðnari stefnu sem styður við og vinnur að réttlæti og jöfnuði fyrir ólíka samfélagshópa. Mikilvægt er að vinna að slíkri stefnu, par sem borgaravitund getur birst með nýjum og margbreytilegum hætti. Í anda hins pólitíska loforðs sem Arendt (2005) lýsir og grundvallast á virðingu fyrir margbreytileika og möguleikum hvers manns til að hafa áhrif ætti ungt flóttafólk á Íslandi að fá hlutdeild í að skapa slíka stefnu enda gegna pau mikilvægu hlutverki í að endurmóta og skapa nýjar hugmyndir um íslenskt samfélag og borgaravitund.

\section{Pakkir}

Kennarar sem tóku pátt í rannsókninni fá miklar pakkir fyrir að veita mikilvæga innsýn inn í nýjar og krefjandi starfsaðstæður. Ólafur Páll Jónsson prófessor við Menntavísindasvið Háskóla Íslands fær pakkir fyrir athugasemdir og yfirlestur. Rannsóknin var styrkt af Jafnréttissjóði Íslands og Eddu - Öndvegissetri við Háskóla Íslands. 


\section{STJÓRNMÁL \& \\ STJÓRNSÝSLA}

\section{Aftanmálsgreinar}

1 Ungt flóttafólk á aldrinum 13-18 ára var spurt sérstaklega út í líðan sína og reynslu í tengslum við stærri könnun á reynslu og viðhorfum flóttafólks hérlendis árið 2005. Við gerð svipaðrar viðhorfskönnunar árið 2017 á vegum Alpjóðamálastofnunar Háskóla Íslands var ekki lögð sérstök áhersla á ungt fólk.

2 Sjá til dæmis alpjóðlegar handbækur: Citizenship Education and Global Migration: Implications for Theory, Research and Teacbing (Banks 2017) og Education for Democracy, Citizenship and Social Justice (Peterson, Hattam, Zembylas \& Arthur 2016).

3 Í svari Velferðarráðuneytis með tölvupósti frá 13. mars 2018 um stjórnsýslulega stöðu stefnuskjalanna tveggja kemur fram að pau séu samin til viðmiðunar fyrir sveitarfélög eða aðra pjónustuveitendur flóttafólks út frá gildandi lögum, reglugerðum og samningum sem gerðir hafa verið. Pau hafi ekki stoð í lögum eða reglugerðum en séu samantekt á löggjöf og reglugerðum sem eiga við pjónustu við tiltekna hópa á peim grundvelli að sú pjónusta sé endurgreidd af ríkissjóði. Ekki er hægt að byggja rétt til pjónustu á umræddum reglum og viðmiðum en hægt er að gera slíkt út frá peim lögum og reglugerðum sem skjölin leggja grunn sinn til.

4 Málefni flóttafólks á Íslandi falla undir Lög um útlendinga (Lög nr. 80/2016). Lögin fjalla hins vegar ekki sérstaklega um menntun barna og ungmenna sem hlotið hafa stöðu flóttafólks á Íslandi umfram almennan rétt barna til menntunar (31. gr.) samkvæmt ákvæðum barnaverndarlaga (80/2002). Lög um útlendinga gefa heimild fyrir pví að fagráðherrar setji reglugerð um aðgang að menntun og starfspjálfun fyrir pá sem hljóta albjóðlega vernd (33. gr.). Pá er einnig ákvæði í lögunum um heimild fyrir reglugerð um menntun, samfélagsfræðslu og starfspjálfun fyrir pann hóp sem hingað kemur 1 boði stjórnvalda (45. gr.). Engar slíkar reglugerðir hafa verið settar af ráðherra menntamála enn sem komið er en skýrsla Ríkisendurskoðunar til Alpingis um málefni útlendinga og innflytjenda á Íslandi frá árinu 2015 greinir frá pví að vinna við reglugerðina hefði átt að fara fram á haustmánuðum 2014. Pá sampykkti Alpingi framkvæmdaráætlun (pingskjal 1692) árið 2016 í málefnum innflytjenda fyrir árin 2016 - 2019 par sem fjallað er um flóttafólk. Í áætluninni er minnst á pátttöku mennta- og menningarmálaráðuneytis í tengslum við mikilvægi pess að flóttafólk hljóti pjónustu og ráðgjöf um réttindi og skyldur í íslensku samfélagi án pess pó að fjallað sé sérstaklega um börn og ungmenni. Árið 2016 kom út skýrsla félags- og húsnæðismálaráðherra um stöðu og próun í málefnum innflytjenda. Skýrslan, líkt og önnur stefnuskjöl, fjallaði ekki sérstaklega um málefni ungs flóttafólks, menntun eða félagslega aðlögun og byggði að miklu leyti á fyrrgreindum stefnuskjölum.

5 Hér er vísað til pess flóttafólks sem kemur til landsins á eigin vegum, sækir um og hlýtur alpjóðlega vernd.

\section{Heimildir}

Alpjóðamálastofnun Háskóla Íslands (2017). Greining á pjónustu við flóttafólk. Reykjavík: Alpjóðamálastofnun Háskóla Íslands, Velferðarráðuneytið og Innanríkisráðuneytið.

Amnesty International (2016). „Tæplega 74\% landsmanna telja að íslensk stjórnvöld ættu að gera meira til að hjálpa flóttafólki“". Sótt af https://www.amnesty.is/starfid-okkar/frettir/taeplega-74-landsmanna-telja-ad-islensk-stjornvold-aettu-ad-gera-meira-til-ad-hjalpa-flottafolki

Anh-Dao, T. (2015). Untapped Resources or Deficient Foreigners': Students of Vietnamese Background in Icelandic Upper Secondary Schools (óbirt doktorsritgerð). Háskóli Íslands, Reykjavík.

Arendt, H. (2005). The promise of politics. New York: Schocken Books.

Arnot, M. og Pinson, H. (2005). The Education of Asylum-Seeker \& Refugee Children. Cambridge UK: Research Consortium on the Education of Asylum-Seeker and Refugee Children.

Auður Magndís Auðardóttir og Berglind Rós Magnúsdóttir (2018, 26. október). "Pað er auđvitað ekeki pverskurdurinn af pjófélaginu sem býr hér”: Um vaxandi stétta- og menningaradgreiningu i skólabverfum böfudborgarsvadisins á árunum 1997-2016. Erindi flutt á Djóðarspegli Háskóli Íslands.

Ásgerður Bergsdóttir og Berglind Rós Magnúsdóttir (2018). „Ólíkur félagslegur og menntapólitískur 
veruleiki íslenskra framhaldsskóla: Nám til stúdentsprófs í 20 ár séð frá sjónarhóli framhaldsskólakennara og stjórnenda“, Netla - Sérrit um frambaldsskólann.

Ball, S.J. (1997). „Policy sociology and critical social research: A personal review of recent education policy and policy research“, British Educational Research Journal 23(3), 257-274.

Ball, S.J. (2015). „What is policy? 21 years later: reflections on the possibilities of policy research“, Discourse: Studies in the Cultural Politics of Education 36(3), 306-313.

Ball, S.J., Maguire, M. og Braun, A. (2012). How schools do policy: Policy enactements in secondary schools. New York: Routledge.

Banks, J. (2017). Citizenship Education and Global Migration: Implications for Theory, Research and Teaching. Washington DC: American Educational Research Association.

Berglind Rós Karlsdóttir (2013). „Pað var auðveldara að hatta bara öllu“. Ástaður brotthvarfs nemenda af erlendum uppruna úr frambaldsskóla á Íslandi (óbirt MA ritgerð). Háskólinn á Akureyri, Akureyri.

Berglind Rós Magnúsdóttir (2013). ,„,Að tryggja framboð og fjölbreytileika“: Nýfrjálshyggja í nýlegum stefnuskjölum um námsgagnagerð“, Uppeldi og menntun 22(2), 55-76.

Berglind Rós Magnúsdóttir (2015). „Meiri árangur, valfrelsi og ráðdeild?“, Uppeldi og menntun 24(1), 8995.

Berglind Rós Magnúsdóttir (2016). „Skóli án aðgreiningar: Átakapólar, ráðandi straumar og stefnur innan rannsóknarsviðsins“, í Dóra S Bjarnason, Ólafur Páll Jónsson og Hermína Gunnpórsdóttir (ritstj.), Skóli margbreytileikeans i kejölfar Salamanca (bls. 67-94). Reykjavík: Háskólaútgáfan.

Berglind Rós Magnúsdóttir og Unnur Edda Garðarsdóttir (2018). „„,Bara ekki mínar týpur!“: Félagsleg aðgreining og framhaldsskólaval”. Netla - Sérrit um frambaldsskólann.

Bergljót Baldursdóttir og Ásgrímur Angantýsson (2012). „Leyfilegt mál og óleyfilegt““. Reykjavík: RÚV - Rás eitt. Sótt af http://www.ruv.is/thaettir/leyfilegt-mal-og-oleyfilegt

Braun, V. og Clarke, V. (2006). „Using thematic analysis in psychology“, Qualitative Research in Psychology 3, 77-101.

Brynja E. Halldórsdóttir, Ólafur Páll Jónsson og Berglind Rós Magnúsdóttir (2016). „Education for democracy, citizenship and social justice: The case of Iceland“, í A. Peterson, R. Hattam, M. Zembylas og J. Arthur (ritstj.), The Palgrave International Handbook of Education for Citizenship and Social Justice (bls. 435-463). London: Palgrave.

Brown, W. (2008). Regulation aversion: Tolerance in the age of identity and empire. Princeton NJ: Princeton University Press.

Castells, S. (2004). „Migration, citizenship and education“, í J. Banks (ritsti.), Diversity and Citizenship Education: Global Perspectives (bls. 17-48). San Francisco CA: Jossey-Bass.

Conell, R. (2013). ,The neo-liberal cascade and education: an essay on the market agenda and its consequences“, Critical Studies in Education, 54(2), 99-112.

Cribb, A. og Ball, S. (2005). „Towards an Ethical Audit of the Privatisation of Education“. British Journal of Educational Studies 53(2), 115-128.

Dillabough, J. (2016). „Gender, social justice and citizenship in education: Engaging space, the narrative imagination and relationality", í A. Peterson, R. Hattam, M. Zembylas og J. Arthur (ritsti.), The Palgrave International Handbook of Education for Citizenship and Social Justice (bls. 49-71). London: Palgrave.

Dóra S. Bjarnason, Hermína Gunnpórsdóttir og Ólafur Páll Jónsson (ritsti.) (2016). Skóli margbreytileikans: Menntun og manngildi i kjölfar Salamanca. Reykjavík: Háskólaútgáfan.

Dudley-Marling, C. (2010). „Confronting the discourse of deficiencies“, Disability Studies Quarterly 30(2), 1241-1285.

ECRI (2017). ECRI report on Iceland. Strassborg: Evrópuráðið.

European Union Agency of Fundamental Rights (2017). Annual Report. Brussel: European Union Agency of Fundamental Rights.

Eva Harðardóttir (2010). Towards a national or global citizenship? Emerging principles of citizenship within compulsory education policies (Óbirt MA ritgerð). Universidad de Deusto, Bilbao.

Evrópumiðstöð um nám án aðgreiningar (2017). Menntun fyrir alla á Íslandi: Úttekt á framkvamd stefnu um 


\section{STJÓRNMÁL $\&$ \\ STJÓRNSÝSLA}

menntun án aðgreiningar á Íslandi. Reykjavík: Mennta- og menningarmálaráðuneytið.

Foucault, M. (2002). The Archaeology of Knowledge (S. Sheridan pýddi). New York: Routledge Classics.

Gestur Guðmundsson (2013). „Innflytjendur i íslenskum framhaldsskólum“. Netla - Veftimarit um uppeldi og menntun. Sótt af http://netla.hi.is/serrit/2013/rannsoknir_og_skolastarf/003.pdf

Gewirtz, S., Mahony, P., Hextall, I. og Cribb, A. (2009). Changing teacher professionalism: International trends, challenges and ways forward. London: Routledge.

Grétar L. Marinósson og Dóra S. Bjarnason (2016). „, Dróun skóla margbreytileikans í kjölfar Salamancayfirlýsingarinnar“", í Dóra S. Bjarnason, Hermína Gunnpórsdóttir og Ólafur Páll Jónsson (ritstj.), Skóli margbreytileikans: Menntun og manngildi i kejölfar Salamanca (bls. 11-37). Reykjavík: Háskólaútgáfan.

Guðbjörg Ottósdóttir og Helena Wolimbwa (2011). Flóttabörn á Íslandi: Rannsókn á viðhorfum og reynslu flóttabarna. Reykjavík: Rannsóknarstofnun í barna- og fjölskylduvernd.

Hagstofan (2017). „Alpjóðleg vernd og dvalarleyfi útlendinga“. Sótt af https://hagstofa.is/utgafur/ frettasafn/mannfjoldi/althjodleg-vernd-og-dvalarleyfi-utlendinga/

Hanna Ragnarsdóttir og Elsa Sigríður Jónsdóttir (2010). Fjölmenning og skólastarf. Reykjavík: Háskólaútgáfan.

Hanna Ragnarsdóttir, Elsa Sigríður. Jónsdóttir og Magnús Dorkell Bernharðsson (ritstj.) (2007). Fjölmenning á Íslandi. Reykjavík: Háskólaútgáfan.

Hermína Gunnpórsdóttir, Stéphanie Barillé og Markus Meckl (2017). „Nemendur af erlendum uppruna: Reynsla foreldra og kennara af námi og kennslu“, Tímarit um Uppeldi og Menntun 26(1-2), 21-41.

Hulda Karen Daníelsdóttir og Hulda Skogland (2018). Staða grunnskólanemenda með íslensku sem annað tungumál. Greining á stöđu og tillögur um ađgerdir. Reykjavík: Menntamálastofnun.

Ingólfur Ásgeir Jóhannesson (2006a). „Um verklag við orðræðugreiningu“, í Rannveig Traustadóttir (ritstj.), Fötlun: Hugmyndir og aðferdir á nýu frađasvidi (bls. 178-195). Reykjavík: Háskólaútgáfan.

Ingólfur Ásgeir Jóhannesson (2006b). "Strong, Independent, Able to Learn More ....: Inclusion and the construction of school students in Iceland as diagnosable subjects", Discourse: Studies in the Cultural Politics of Education 27(1), 103-119.

Ingólfur Ásgeir Jóhannesson (2007). „Fjölmenning og sjálfbær próun: Lykilatriði skólastarfs eða ópægilegir aðskotahlutir?" Netla - Veftímarit um uppeldi og menntun. Sótt af http://netla.hi.is/greinar/2007/018/index.htm

Ingólfur Ásgeir Jóhannesson (2013). „Grunnskólakennarar í aftursætinu og leikskólakennarar í skottinu“, í Rúnar Sigpórsson, Rósa Eggertsdóttir og Guðmundur Heiðar Frímannsson (ritstj.), Fagmennska í skólastarfi. Skrifað til heiður Trausta Porsteinssyni (bls. 131-151). Reykjavík: Háskólaútgáfan og Háskólinn á Akureyri.

Kristín Dýrfjörð, Dórður Kristinsson og Berglind Rós Magnúsdóttir (2013). Jafnrétti: Grunnpáttur í menntun á öllum skólastigum. Reykjavík: Mennta- og menningarmálaráðuneytið.

Kristín Erla Harðardóttir, Heiður Hrund Jónsdóttir og Friðrik H. Jónsson (2005). Reynsla og viðhorf flóttamanna á Íslandi. Reykjavík: Flóttamannaráð.

Kristín Loftsdóttir (2012). „Whiteness if from another world: Gender, Icelandic international development and multiculturalism", European Journal of Women Studies 19(1), 41-54.

Kristín Loftsdóttir (2018). ,„,Ég elti auðinn til Evrópu“. Sögur af fólki á flótta, innflytjendum og „ólöglegum" einstaklingum", Ritid 18(2), 159-184.

Lög um framhaldsskóla nr. 92/2008.

Lög um grunnskóla nr. 91/2008.

Maja Loncar (2016). Reynsla ungs flóttafólks á Íslandi: Takeifari, áskoranir og vonir og vantingar i nýju landi (óbirt MA-ritgerð). Háskóli Íslands, Reykjavík.

Maskína (2015). „Stuðningur við innflytjendur“. Reykjavík: Maskína. Sótt 10. September af https:// kjarninn.is/frettir/mikill-munur-a-vidhorfi-islendinga-til-innflytjenda-eftir-uppruna-theirra/

Menntamálastofnun (2016). Helstu niðurstöður PISA 2015. Reykjavík: Menntamálastofnun.

Ólafur Páll Jónsson (2011). Lýdrađi, réttlati og menntun: Hugleiding um skilyrdi mennskunar. Reykjavík: Háskólaútgáfan. 
Ólafur Páll Jónsson (2014). „Lýðræðisleg menntastefna: Sögulegt ágrip og heimspekileg greining“, Stjórnmál \& stjórnsýsla 10(1), 99-118.

Ólafur Páll Jónsson (2018). „Lýðræði og borgaravitund: Hugsjón, stefna og tómarúm“, í Vilhjálmur Árnason og Henry Alexander Henryson (ritsti.), Hvad einkennir islensket lýdradi: Starfsvenjur, gildi og skilningur. Reykjavík: Háskólaútgáfan.

Rangvid, B.S. (2010). „School Choice, Universal Vouchers and Native Flight from Local Schools*“, European Sociological Review 26(3), 319-335. http://dx.doi.org/10.1093/esr/jcp024

Reay, D. (2004). „Education and cultural capital: The implications of changing trends in education policies“, Cultural Trends 13(2), 73-86.

Sigrún Ólafsdóttir (2018). Hverjir eru velkomnir á Íslandi? Viðhorf til innflytjenda 2004-2016. Erindi var flutt á Íslensk pjóðfélagsfræði, Bifröst.

Slee, R. og Allan, J. (2001). „Excluding the included: A reconsideration of inclusive education“, International Studies in Sociology of Education 11(2), 173-192.

Steingerður Ólafsdóttir, Sigrún Sif Joelsdóttir, Lára Rún Sigurvinsdóttir, Dóra S Bjarnason, Anna Kristín Sigurðardóttir og Kristín Erla Harðardóttir (2015). Skóli án aðgreiningar: Samantekt á lögum og fræðilegu efni. Reykjavík: Menntavísindasvið HÍ, Mennta og menningarmálaráðuneytið.

Stella Blöndal, Jón Torfi Jónasson og Anne-Christine Tannhäuser (2011). „Dropout in a small society: Is the Icelandic case somehow different?", í S. Lamb, E. Markussen, R. Teese, N. Sandberg og J. Polesel (ritsti.), School Dropout and Completion: International Comparative Studies in Theory and Policy (bls. 233-252). London: Springer.

Tarozzi, M. og Torres, C. (2016). Global Citizenship Education and the Crisis of Multiculturalism: Comparative Perspectives. London: Bloomsbury.

Thomson, P. (2014). ,'Scaling up’ educational change: some musings on misrecognition and doxic challenges", Critical Studies in Education 55(2), 87-103.

UNHCR (2017). Statistical Yearbook 2016. New York: UNHCR.

Unnur Dís Skaptadóttir og Pamela Innes (2017). „Immigrant Experiences of Learning Icelandic and Connecting with the Speaking Community", Nordic Journal of Migration Research 7(1), 20-27.

Útlendingastofnun (2017). ,Tölfræði verndarsviðs“. Sótt af https://www.utl.is/index.php/um-utlendingastofnun/toelfraedhi/toelfraedhi-verndarsvidhs\#Eldri $\% 20 \mathrm{t} \% \mathrm{C} 3 \% \mathrm{~B} 6 \mathrm{lfr} \% \mathrm{C} 3 \% \mathrm{~A} 6 \% \mathrm{C} 3 \% \mathrm{~B} 0 \mathrm{i}$

Velferðarráðuneytið (2017). „Fjöldi flóttamanna“. Sótt af https://www.stjornarradid.is/verkefni/utlendingar/flottafolk/ fjoldi-flottamanna/

WRC og UNHCR (2016). „We believe in youth“. New York: Global Refugee Youth Consultation. 